\title{
Advances in research on ACE2 as a receptor for 2019-nCoV
}

\author{
Jie $\mathrm{Wu}^{1} \cdot$ Wei Deng ${ }^{2} \cdot$ Shumin $\mathrm{Li}^{1,3} \cdot$ Xiuhong Yang ${ }^{1,3}$ (1) \\ Received: 28 April 2020 / Revised: 21 July 2020 / Accepted: 30 July 2020 / Published online: 11 August 2020 \\ (c) Springer Nature Switzerland AG 2020
}

\begin{abstract}
Currently, a novel coronavirus (SARS-CoV-2, also called 2019-nCoV) has triggered pandemic Coronavirus Disease 2019 (COVID-19), an acute infectious respiratory disease that first became epidemic in Wuhan (China) and is now spreading worldwide. Although 2019-nCoV and SARS-CoV are very similar viruses genomically and structurally, the huge number of severe cases and deaths now being caused by 2019-nCoV infections has understandably prompted intense research on the receptor used by it to enter human cells. Angiotensin converting enzyme 2 (ACE2), a functional receptor for SARS-CoV, now appears likely to mediate 2019-nCoV entry into human cells. In this review, we describe the roles performed by ACE2 as an enzymatic catalyst and as a receptor for this novel coronavirus. We also summarize the latest research pertaining to the changes noted in ACE2 expression after viral binding, and the relationships relating to virus transmission and population susceptibility to it. Lastly, we speculate on the pathogenesis of COVID-19 and provide a useful reference for drug development against this aggressive virus.
\end{abstract}

Keywords Angiotensin converting enzyme $2 \cdot 2019-\mathrm{nCoV} \cdot$ Virus receptor $\cdot$ Coronavirus $\cdot$ Renin angiotensin system . Immune function

\section{Introduction}

The new SARS-like acute infectious respiratory disease has now reached pandemic levels. First emerging in Wuhan in December 2019 in the Hubei Province of China, it was temporarily called "novel coronavirus pneumonia (NCP)" by China's National Health Commission. Studies have shown that the disease is caused by a novel coronavirus $(\mathrm{CoV})$,

Xiuhong Yang

yangxiuhong@ncst.edu.cn

1 Hebei Key Laboratory for Chronic Diseases, Tangshan Key Laboratory for Preclinical and Basic Research On Chronic Diseases, School of Basic Medical Sciences, North China University of Science and Technology, No. 21 Bohai Road, Caofeidian Eco-city, Tangshan 063210, Hebei, China

2 NHC Key Laboratory of Human Disease Comparative Medicine, Beijing Key Laboratory for Animal Models of Emerging and Remerging Infectious Diseases, Institute of Laboratory Animal Science, Chinese Academy of Medical Sciences and Comparative Medicine Center, Peking Union Medical College, Beijing 100021, China

3 Hebei Key Laboratory for Organ Fibrosis, School of Public Health, North China University of Science and Technology, No. 21 Bohai Road, Caofeidian Eco-city, Tangshan 063210, Hebei, China officially named 2019-nCoV, and now referred to as SARSCoV-2 by scientists [1]. The US Food and Drug Administration named this new epidemic infectious disease coronavirus disease 2019 (COVID-19). Epidemiological studies have shown that 2019-nCoV can spread rapidly through person-to-person transmission routes, which include coughs, sneezes, droplet inhalation, and other contact transmission. The disease, which is now rapidly spreading around the globe, has become an international public health emergency. The clinical symptoms of COVID-19 include fever, dry cough, fatigue, dyspnea, respiratory failure, and even death in severe cases. Although preliminary experiments by researchers or research institutions have reported that some agents may be effective against 2019-nCoV, there are currently no effective drugs targeting 2019-nCoV/SARS-CoV-2 [2].

Mammalian angiotensin-converting enzyme 2 (ACE2) was first discovered in the human lymphoma cDNA library by the Tipnis team [3] and a human heart failure ventricle cDNA library by Donoghue team [4] in 2000. During the SARS outbreak in 2003, ACE2 was identified by Li et al. [5] as a functional receptor for SARS-CoV in that it mediated the viral invasion of host cells, a finding later confirmed in animal experiments [6]. Some recent studies have suggested 
that 2019-nCoV may infect host cells through the ACE2 receptor, as has already been established for SARS-CoV [7-10]. Accordingly, ACE2, as a 2019-nCoV receptor, may be a potential target for the treatment of COVID-19. In this review, the latest advances in our understanding of the roles played by ACE2 in enzyme catalysis, $\mathrm{CoV}$ invasion, cellular expression changes after viral-host cell binding, and its relationships with viral transmission and population susceptibility are described in the context of the pathogenesis of COVID-19. This review aims to provide a reference for the development of ACE2-targeted drugs for 2019-nCoV.

\section{Physiological role of ACE2}

\section{Discovery and characterization of ACE2}

In 1995, a protein highly homologous to mammalian somatic angiotensin-converting enzyme (ACE), was isolated and purified from Drosophila melanogaster embryos and named AnCE [11]. In 1996, researchers identified another Drosophila gene whose predicted translation product shared homology with mammalian testicular ACE and with AnCE and called it Ace-related (Acer), after which it was renamed ACE-like protein [12]. Insect AnCE and ACE-like protein then became classified as "ACE-like enzymes" [3].

In 2000, scientists also discovered ACE-like enzymes in mammals. Tipnis et al. [3] were the first researchers to clone a human metalloproteinase with high homology to ACE, calling it "ACE homolog (ACEH)" or "ACE related carboxypeptidase", latterly known as "angiotensin-converting enzyme 2 (ACE2)" by Donoghue team [4]. The sequence identity between ACE2 and ACE is about $40 \%$, with a similarity score of $61 \%$ [3], while the sequence similarity between mouse and human ACE2 is about 83\% [13]. The human ACE2 gene is located on the short arm of the X chromosome and contains 18 exons. The complete human ACE2 cDNA encodes an 805 amino acid protein with a molecular weight of $120 \mathrm{kD}$ [3]. Membrane-associated ACE2 is a type I transmembrane protein consisting of a signal peptide at the amino terminal, a single metalloproteinase active site containing a zinc ion binding motif (i.e., HEMGH), a transmembrane domain, and a small cytoplasmic domain at the carboxyl terminus. A variety of transmembrane proteins can be cleaved by proteolytic enzymes to release the catalytically functional and free-standing extracellular domain, thereby regulating their activities [3, 14]. ACE2, like ACE, is a cleavable, extracellular enzyme located on the cell surface membrane [15]. ADAM17, a metalloproteinase family member, can cleave membrane-bound ACE2 and release its extracellular portion into the circulation as soluble ACE2 (sACE2), which lacks the transmembrane and cytoplasmic domains but retains its activity [14]. It has been shown that the activity of sACE2 is suppressed by the presence of an endogenous inhibitor in the form of a currently unknown positively charged small molecule [16].

\section{ACE2 catalysis and the renin-angiotensin system (RAS)}

RAS, one of the most important hormonal mechanisms for maintaining homeostasis in the human body, regulates blood pressure, fluid volume, and sodium-potassium balance. RAS, which is located in the circulation and in local tissues, is linked with many diseases such as cardio and cerebral vascular diseases, and diabetes mellitus, among others [17]. The classical RAS encompasses ACE, Ang II, the AT1 receptor, and other molecules, collectively forming the ACE-Ang II-AT1 axis. As a dicarboxypeptidase, ACE can catalyze the conversion of Ang I to Ang II, after which Ang II binds to the AT1 receptor to play roles in promoting vasoconstriction, inflammation and proliferation. The discovery of ACE2 suggests that there is another ACE2-Ang-(1-7)Mas receptor pathway in the RAS, which is contrary to the classical pathway [18]. ACE2, a monocarboxyl peptidase, contains an $\mathrm{N}$-terminal peptidase domain (PD) and a C-terminal collectrin-like domain (CLD) [4]. The N-terminal PD directly hydrolyzes Ang II into Ang-(1-7), or firstly Ang I into Ang-(1-9), which can later be hydrolyzed to Ang-(1-7) by ACE or other enzymatic molecules. Ang-(1-7) exerts the opposite effect of Ang II (i.e., vasodilation, anti-inflammation and anti-proliferation) by activating Mas receptor [18]. In fact, RAS metabolic pathways are not only limited to the two above-mentioned pathways, but some alternative pathways as well, such as Ang II formation via the chymase pathway and Ang-(1-7) formation directly from Ang I by prolyl endopeptidase or neutral endopeptidase [18] (Fig. 1).

\section{CoV structure and characteristics of 2019-nCoV}

CoVs are a large group of spherical, $120-160 \mathrm{~nm}$ in diameter, positive-sense viruses with single-stranded RNA genomes. $\mathrm{CoV}$ genomes, ranging from 26 to $32 \mathrm{~kb}$ in size, are the largest among the known RNA viruses. The RNA genomes of CoVs can serve as messenger RNAs and can be translated directly into proteins in the ribosomes of host cells [19]. To date, seven CoV types are known to infect humans, among which HCoV-229E, HCoV-NL63, HCoV-OC43 and HCoV-HKU1 only cause common cold symptoms, whereas the other three types, SARS-CoV, MERS-CoV and 2019$\mathrm{nCoV}$, are highly transmissible with high fatality rates [20].

The CoV genome comprises a 5'-cap structure and 3'poly-A tail. The 5'-terminal-located two-thirds of $\mathrm{CoV}$ genes mostly encode the non-structural proteins that form 


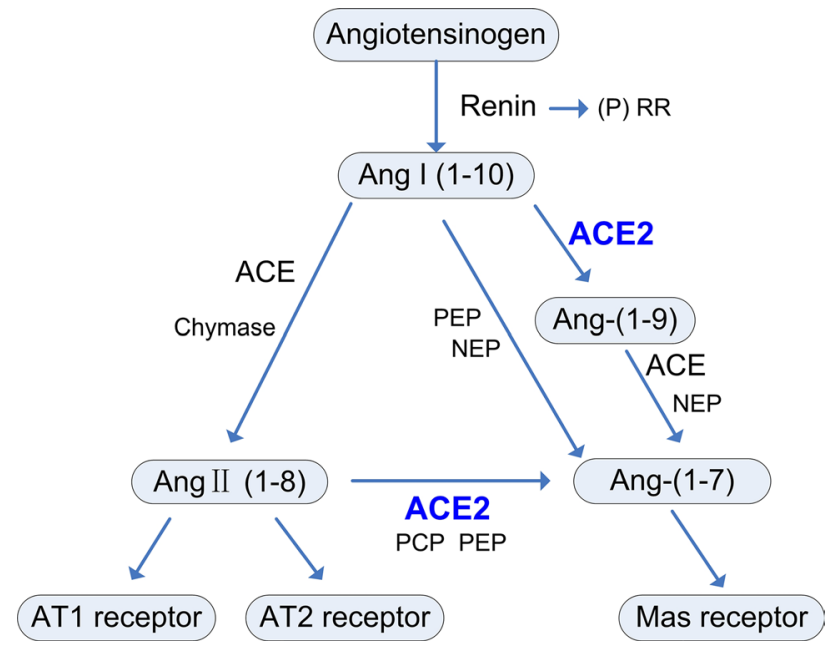

Fig. 1 The metabolic pathway of the rennin-angiotensin system. The RAS system mainly encompasses two axes: the classical RAS ACEAng II-AT1 regulatory axis and the ACE2-Ang-(1-7)-Mas counter-regulatory axis. (P) RR, (pro) renin receptor; Ang, angiotensin; $\mathrm{ACE}$, angiotensin-converting enzyme; ACE2, angiotensin-converting enzyme 2; NEP, neutral endopeptidase; PEP, prolyl endopeptidase; $\mathrm{PCP}$, prolyl carboxypeptidase

polymers and perform replication and translation functions. One-third of the genome near the 3'-terminus encodes at least four main structural proteins; namely, spike (S), envelope (E), membrane (M) and nucleocapsid (N) [21]. The $\mathrm{S}$ protein forms radially protruding trimers on the viral envelope, which mediate virus-receptor binding and membrane fusion. So, the S protein is a key protein for determining the host range and transmission ability of CoVs [19]. The S protein is structurally divided into two functionally distinct subunits called the $\mathrm{S} 1$ and $\mathrm{S} 2$ subunits. While the $\mathrm{S} 1$ subunit is responsible for receptor binding and includes the $\mathrm{N}$-terminal domain and C-terminal receptor binding region (RBD), the $\mathrm{S} 2$ subunit facilitates membrane fusion and anchors $\mathrm{S}$ into the viral membrane [22].

Annotation of the 2019-nCoV genome shows that it possesses 14 open reading frames (ORFs) encoding 27 proteins [23]. Although HCoV-NL63, 2019-nCoV and SARS-CoV all invade host cells via ACE2 receptors, only the latter two viruses share homology and similarity in their genome sequences [23, 24]. 2019-nCoV and SARS-CoV are both $\beta \mathrm{CoVs}$, sharing the highest nucleotide sequence identity (79.7\%) across their whole genomes [25]. The main difference between them lies in ORF1a and the gene sequence encoding the $\mathrm{S}$ protein. Homology modeling shows that the receptor domain of 2019-nCoV has a similar receptor-binding domain as SARS-CoV $[8,10]$.

Structural analyses have revealed that the $\mathrm{E}$ and $\mathrm{N}$ proteins in 2019-nCoV show evolutionary conservation, with sequence identities of $96 \%$ and $89.6 \%$, respectively, as compared with SARS-CoV [25]. In contrast, multiple mutations in 2019-nCoV are present in its $\mathrm{S}$ and $\mathrm{M}$ structural proteins when compared with bat-CoV, revealing that different selection pressures have been exerted on 2019-nCoV during its evolutionary history [26]. Previous studies have indicated that positions $442,472,479,487$, and 491 are important amino acid residues interacting with ACE2 in the SARS$\mathrm{CoV} S$ protein and are considered to be crucial for the cross-species and person-to-person transmission of SARS$\mathrm{CoV}$ [27]. Although the RBD domain of the S protein from 2019-nCoV is highly conserved in its sequence, as compared with SARS-CoV, amino acids at four important positions in five key residues are replacements with only Tyr491 being retained [10]. The 2019-nCoV and SARS-CoV S proteins, nevertheless, still share an almost identical 3D structure in the RBD domain. Thus, similar van der Waals forces and electrostatic properties are still predicted to occur at the interaction interfaces of both viruses, although the binding affinity of 2019-nCoV for ACE2 is significantly higher than that of SARS-CoV [10].

\section{ACE2 as a receptor for CoVs}

\section{Identification of ACE2 as a viral receptor in the human host}

During the SARS outbreak in 2003, Li et al. [5] were the first research group to identify ACE2 as a functional receptor for SARS-CoV. They first found that $293 \mathrm{~T}$ cells transfected with ACE2 formed multinucleated syncytia in cells expressing the S protein. They also found that SARS-CoV could replicate effectively in non-susceptible cells transfected with ACE2, while an anti-ACE2 antibody was found to block viral replication in E6 Vero cells. The above in vitro experiments led them to conclude that ACE2 is a functional receptor for SARS-CoV, and mediates viral entry into host cells.

Three in vivo experiments using humanized ACE2 transgenic (hACE2) mice infected with SARS-CoV were reported in 2007. Under the regulation of CAG-complex promoters, including cytomegalovirus immediate-early (CMV-IE) enhancers and chicken $\beta$-actin promoters, the hACE2 gene was expressed in the lungs, small intestines, and livers (at the mRNA level) of AC70 transgenic mice. The mice showed clinical manifestations such as weight loss after being attacked by virus, and all died within 8 days [28]. Under the control of the cytokeratin 18 promoter, the hACE2 gene was expressed in alveolar epithelial cells and the liver, kidneys and gastrointestinal epithelial cells of another transgenic mouse, and rapid death also occurred after viral infection [29]. The transgenic mouse with the endogenous mACE2 promoter was found to have hACE2 expression in its lungs, heart, kidneys and intestines at both the mRNA and protein levels. Dissimilar to the above two mice showing 
lethal SARS-CoV infections, none of the hACE2 transgenic mice challenged with SARS-CoV died; however, the viral titers in their lung tissues had significantly increased above normal and serious pathological changes in their lung tissues and multiple organ damage was apparent, thereby establishing a susceptible animal model for SARS-CoV [30].

Recently, some researchers have shown that ACE2 can be used as a 2019-nCoV receptor using molecular models and in vitro experiments. Zhou et al. [7] first performed viral transfection experiments using HeLa cells expressing or not expressing ACE2. The results showed that 2019-nCoV could only enter HeLa cells expressing human ACE2, thus confirming that 2019-nCoV is likely the cell receptor for 2019$\mathrm{nCoV}$ [7]. Another study demonstrated that expression of human or bat ACE2 in non-susceptible BHK-21 cells can enable 2019-nCoV and SARS-CoV to enter cells, and that anti-serum raised against human ACE2 can block SARS-S and 2019-nCoV S-driven cell entry [31]. A genomic characterization and homology modeling study on the origins of 2019-nCoV revealed the existence of structural similarities in the receptor binding domains of SARS-CoV and 2019$\mathrm{nCoV}$ [8]. In other research on the potential receptor for 2019-nCoV, the sequence of 2019-nCoV RBD, including its receptor-binding motif that directly contacts ACE2, was found to be similar to that of SARS-CoV [9].

ACE2-binding affinity has been shown to be one of the most important factors determining the infectivity of SARSCoV [9]. Recently, Yan et al. [32] analyzed the interface between ACE2 and 2019-nCoV-RBD and SARS-RBD complexes to reveal variations that may determine the different affinities of the RBDs in the two related viruses. Some researchers have used molecular models to show that the 2019-nCoV RBD domain penetrates the deep hydrophobic pocket of ACE2, resulting in a stronger interaction with ACE2 than SARS-CoV [33]. Wrapp et al. [34] analyzed the structure of the 2019-nCoV S protein trimer by cryoelectron microscopy and found that the binding capacity of the $\mathrm{S}$ protein from 2019-nCoV to the ACE2 receptor was 10- to 20-fold higher than that of SARS-CoV. Interestingly, Coutard et al. [35] identified a peculiar furin-like cleavage site in the S protein from 2019-nCoV, possibly explaining why $2019-n C o V$ seems to be readily transmitted between humans.

Recently, humanized transgenic animal modeling has further demonstrated that ACE2 can mediate host cell invasion by $2019-n C o V$. In an experiment where hACE2 transgenic mice were infected with 2019-nCoV, viral antigens were observed in bronchial epithelial cells, alveolar epithelial cells and macrophages in the transgenic mice, while no viral antigens were found in their infected wild-type counterparts [36]. Therefore, it is speculated that like SARS-CoV, 2019nCoV infects host cells via the mediating effects of its $\mathrm{S}$ protein and ACE2 receptors on the surfaces of human cells.
As a point of reference, HCoV-NL63, which was discovered in the Netherlands in 2004, shares no structural homology with SARS-CoV, but also utilizes the ACE2 receptor when invading host cells. However, the crystal structure has showed that the HCoV-NL63 RBD domain binds to a narrower region of ACE2, involving fewer amino acids, which would lead to a weaker interaction. However, NL63-CoV does not have as aggressive transmission as SARS-CoV or the newer-discovered 2019-nCoV, so its pathogenicity is weak and any relevant research on it is scarce [24].

\section{The ACE2 receptor mediates viral entry into cells}

ACE2 as a receptor may mediate the entry of CoV into host cells in two independent ways (Fig. 2).

The first way involves ACE2-receptor-mediated clathrindependent endocytosis. The RBD of the virus is recognized by the extracellular PD of ACE2 mainly through polar residues. When $\mathrm{CoV}$ is connected to ACE2, the ACE2 extracellular domain controlling the catalytic effect is cleaved off by specific proteases, such as metalloproteinase ADAM17, and the transmembrane domain is internalized. Next, with the assistance of clathrin [37], viral particles and host cells fuse, and the intracellular structure of ACE2 aids viral transport from the cell membrane to the cytoplasm. In vitro studies have shown that ADAM17 inhibitors can attenuate virus replication [38]. Although the physiological function of ACE2 extracellular shedding has not been fully elucidated, it has been shown to be associated with virus invasion and replication [38, 39]. sACE2 retains catalytic activity and can partially block SARS-CoV binding to receptors on target cells, and one in vitro study has shown that SACE2 could block the association between the S1 domain of SARS-CoV and E6 Vero cells and reduce viral replication [5]. Cells expressing ACE2 non-catalytic mutants can still be infected by SARS$\mathrm{CoV}$, and the enzymatic activity of ACE2 did not contribute to S-protein-mediated infection by this virus [40], indicating that the peptidase action of ACE2 is not necessary for viral entry into host cells. Elsewhere, structural analysis has shown that the metallopeptidase domain of ACE2 can be divided into two subdomains (I and II), with the CoV S protein contacting the top of subdomain I of the ACE2 catalytic domain, but the $\mathrm{S}$ protein does not contact subdomain II or seal the peptidase activity sites in ACE2 [41].

The second way involves ACE2-receptor-mediated transmembrane serine protease 2 (TMPRSS2)-dependent membrane fusion. One study found that ACE2-mediated viral invasion involves TMPRSS2, which is employed for $\mathrm{S}$ protein priming and activation of membrane fusion processes [42], and TMPRSS2s priming role has recently been confirmed for 2019-nCoV [31]. When the SARS-S protein binds to ACE2, processing by TMPRSS2 is thought to allow fusion at the cell surface or upon uptake into cellular vesicles 


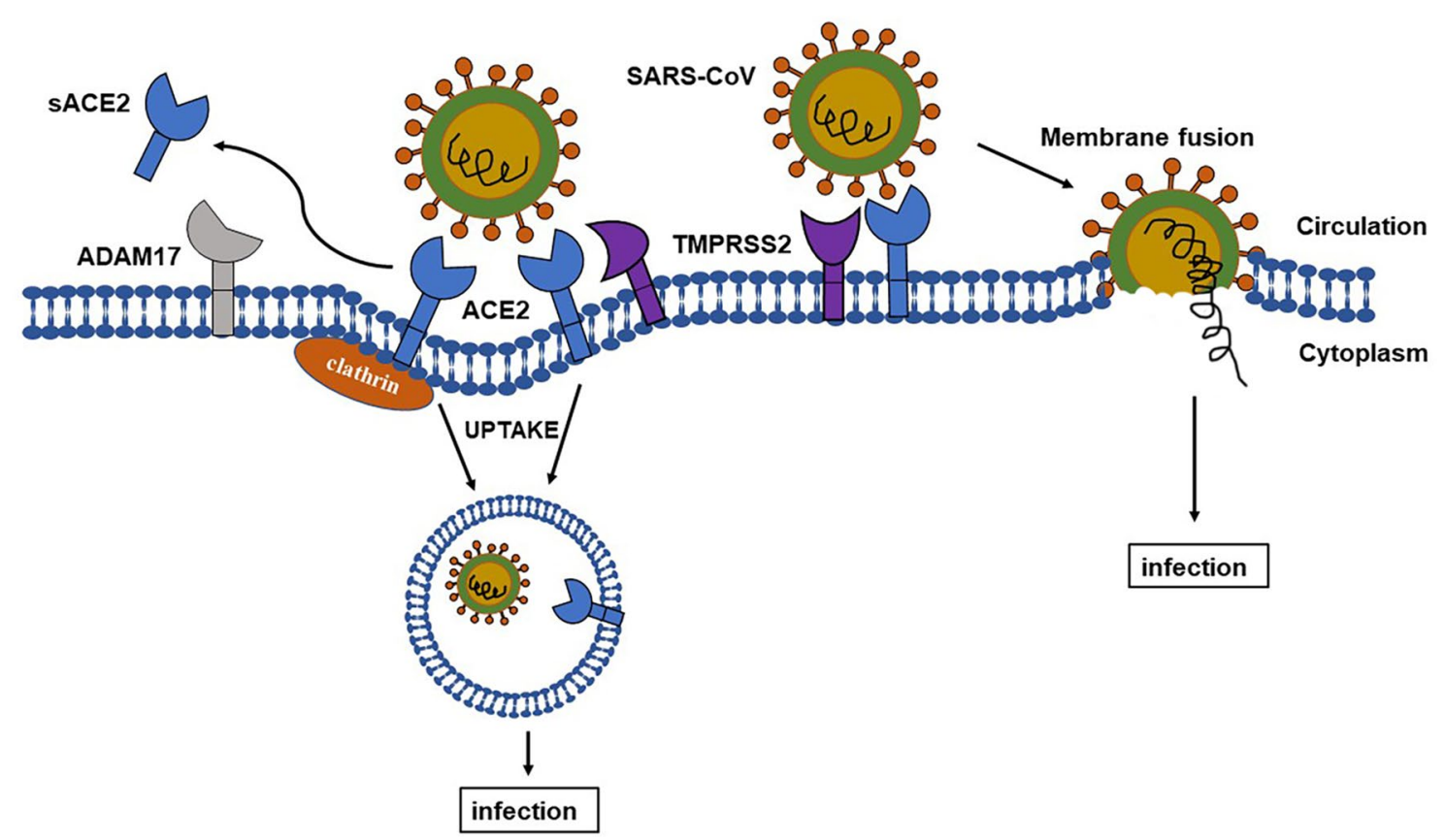

Fig. 2 The viral invasion process of host cells via the ACE2 receptor. ACE2 as a receptor may mediate the entry of $\mathrm{CoV}$ into host cells via two distinct routes. The first involves clathrin-dependent endocytosis;

but before virion transport into cell endosomes. TMPRSS2 has also been found to compete with the ADAM17 metalloprotease for ACE2 processing, but only cleavage by TMPRSS2 was found to enhance SARS-S protein-driven entry [42]. The molecular mechanism underlying proteaseenhanced cell entry and the potential role of ACE2 cleavage upon SARS-S protein activation are unclear [42]. Research using the 2019-nCoV S protein pseudovirus system and different inhibitors has shown that 2019-nCoV enters 293/ hACE2 cells mainly by endocytosis, and that phosphatidylinositol 3-phosphate 5-kinase, two pore channel subtype 2 , and cathepsin L are critical for viral entry. Another study revealed that 2019-nCoV S protein can trigger syncytia in 293/hACE2 cells independent of an exogenous protease [43].

Recent resolution of the full-length structure of human ACE2 using cryo-electron microscopy by Yan et al. [32] indicated that ACE2 exists as a dimer with both "open" and "closed" conformations. Conversion of the two conformations is achieved by rotation of the PD domains in ACE2, and both conformations contain the mutual recognition interface with CoVs. Further studies have shown that ACE2 dimers can accommodate two $S$ protein trimers through each ACE2 monomer [44]. ACE2 is also a chaperone protein for membrane transportation of the amino acid transporter B0AT1 (also called SLC6A19) [45], which mediates the uptake of neutral amino acid-like substances into intestinal cells in a sodium-dependent manner. These findings suggest the second involves ACE2 receptor-mediated TMPRSS2-dependent membrane fusion. ADAM17, a disintegrin and metallopeptidase domain 17; TMPRSS2, transmembrane serine protease 2

that B0AT1 may play a regulatory role in intestinal infection with some CoVs [44]. Further research indicates that the presence of B0AT1 may block TMPRSS2s access to the cutting site on ACE2; therefore, the role played by the ACE2/B0AT1 dimer structure in conformational binding of the 2019-nCoV S protein appears to affect the viral invasion of host cells. Whether B0AT1 can inhibit 2019-nCoV infection by blocking ACE2 cleavage remains an unanswered question [44].

\section{Changes in ACE2 expression after binding to CoV}

ACE2 gene expression is regulated at both the transcriptional and post-transcriptional levels by a variety of mechanisms. Ang II/AT1 can upregulate ACE2 mRNA and protein expression in human cardiac fibroblasts via the ATTTGG A promoter sequences in the -516 to -481 regions of the gene [46]. While Ang II/AT1 promotes extracellular ACE2 internalization followed by lysosomal degradation [47], ADAM17 cleaves membranes bearing ACE2, thereby releasing SACE2 into the circulation [14]. Furthermore, microRNAs such as miR-421 can mediate ACE2 gene silencing in cardiac fibroblasts and a variety of human tissue cell lines [48]. Thus, these mechanisms of expression and activity regulation of ACE2 play an important role in cardiovascular and other diseases. 
Interestingly, one study has suggested that ACE2 expression is downregulated after viral infection. In their 2005 study, Kuba et al. [6] showed that SARS-CoV infection and SARS-CoV S proteins reduce the expression of ACE2 in lungs (but not ACE), lead to increased Ang II levels, signaling through the AT1 receptor, increased pulmonary vascular permeability, and acute lung injury induction. Notably, ACE2 is not only a receptor for viral invasion of host cells during SARS-CoV infection, but viral binding to it deregulates its protective effect on the lungs. This may explain why SARS-CoV is more lethal in humans than other CoVs [49]. Oudit et al. [50] demonstrated that SARS-CoV was also strongly equipped to infect the heart and modulate ACE2 expression in this organ. Pulmonary infections with SARS$\mathrm{CoV}$ in wild-type mice subsequently led to downregulation of myocardial ACE2 mRNA and loss of ACE2 protein in an ACE2-dependent manner. Furthermore, the presence of SARS-CoV in the heart in patients who died from SARS was associated with macrophage infiltration and myocardial damage in association with decreased myocardial ACE2 protein expression. Collectively, these findings suggest that myocardial ACE2 downregulation may be an underlying pathophysiological mechanism for SARS-associated heart disease.

Recently, some researchers have speculated that 2019nCoV causes ACE2 downregulation by binding to the ACE2 receptor, and they have proposed strategies to treat COVID19 infections with ACE2 as the target, which involves using the TMPRSS2 inhibitor to prevent $\mathrm{CoV} S$ protein-ACE2 binding $[31,51]$, blocking the ACE2 receptor using antiACE2 antibodies or peptides, or using sACE2 to attenuate viral invasion through competitively binding with 2019$\mathrm{nCoV}$, thereby protecting against lung injury through its unique enzymatic properties [51]. Supporting such strategies is the finding from Wang et al. [52], who showed that, individually, SARS-CoV or 2019-nCoV S proteins can interact with ACE2 on the surface of host cells and become separately internalized together with ACE2 through endocytosis, resulting in reduced surface ACE2 expression [53]. This endocytic event also upregulates ADAM17 activity, which in turn cleaves ACE2 on cell membrane surfaces, perpetuating the loss of the ACE2 protective effect in tissue RAS. Loss of ACE2 leads to imbalance of RAS homeostasis and increased Ang II levels, causing damage to the organism through AT1 receptors, while also upregulating ADAM17 activity in a well characterized positive feedback loop leading to further cleavage of cell surface attached ACE2 [52]. One study reported that the level of Ang II in the plasma of 2019-nCoV-infected patients is significantly higher than in uninfected individuals, a finding linearly correlated with viral load and the degree of lung injury [54]. ADAM17 also mediates the liberation of the membrane bound precursors of tumor necrosis factor $\alpha$ (TNF $\alpha$ ), interferon (IFN)- $\gamma$, and IL-4 (interleukin-4) proinflammatory cytokines into the circulation [39], which also downregulates ACE2 expression on the cell surface and decreases ACE2 mRNA levels. Soluble recombinant human ACE2 (rhACE2) inhibits viral invasion of host cells by competitive binding with 2019-nCoV, limits

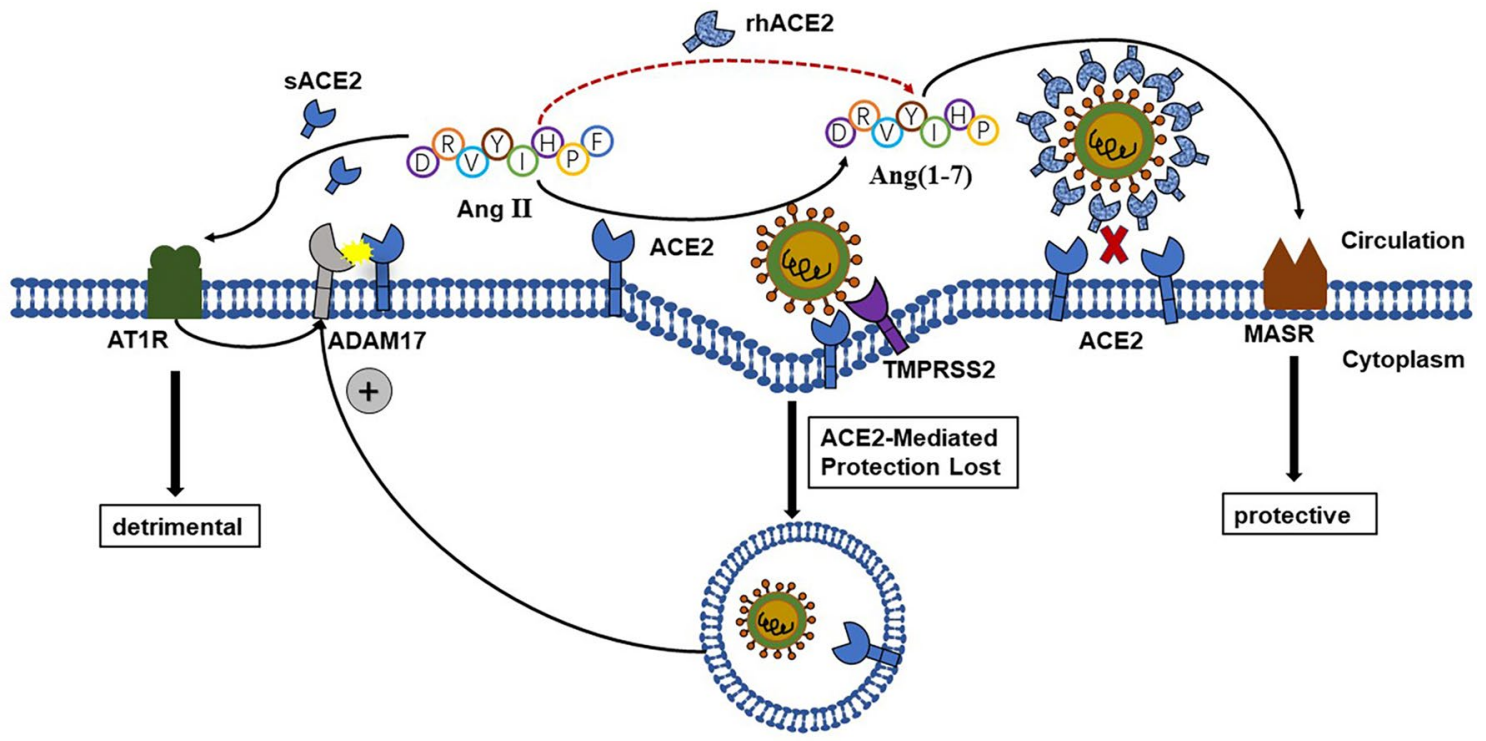

Fig. 3 The proposed mechanism underlying 2019-nCoV-induced downregulation of cell surface ACE2 expression. CoV interacting with ACE2 becomes internalized together with ACE2 through endocytosis, which upregulates ADAM17-mediated proteolytic cleavage of ACE2. Loss of ACE2 leads to accumulation of angiotensin
II, which also increases ADAM17 activity through AT1 receptors. rhACE2 inhibits viral invasion of host cells by competitive binding to $\mathrm{CoV}$ with membrane ACE2, limits the activities of Ang II, and increases protective Ang-(1-7) levels 
the activities of Ang II, and increases protective Ang-(1-7) levels [52, 55] (Fig. 3). Elsewhere, Monteil et al. [56] found that rhACE2 can prevent 2019-nCoV from infecting human blood vessel organoids and human kidney organoids engineered via the induction of pluripotent stem cells and addition of rhACE2 also showed no cellular toxicity. However, because it has only been shown that rhACE2 can block the early stages of 2019-nCoV infections, this finding requires confirmatory clinical evidence.

However, some researchers have the opposite viewpoint, suggesting that ACE2 expression is upregulated by viral infection. A team at Shandong University (China) searched databases for cells and tissues known to be stimulated by viral infections or inflammatory cytokines, and they clearly showed that ACE2 can be significantly upregulated by virus infection and inflammatory cytokine stimulation [57]. The ACE2 gene is responsive to viral infections, and its expression can be stimulated by a variety of viruses. When upregulated, ACE2 is more receptive to viral invasion and transmission, while its induction by inflammatory cytokines also implies that the "cytokine storm" caused by 2019-nCoV not only damage host tissues, but may also accelerate viral spread [57]. Their analysis also showed that there are multiple transcription factor binding sites related to immune and cytokine responses in the promoter region of ACE2. It is speculated that the activated immune system induces the expression of a variety of cytokines, including IFN, after viral infection, which promotes the transcription and expression of ACE2 by activating downstream signaling pathways such as the JNK (c-Jun N-terminal kinase) pathway. Ziegler et al. [58] showed that IFNs increase ACE2 in human nasal epithelia and lung tissue, and ACE2 belongs to a large family of interferon-stimulated genes (ISGs), and suggested that 2019-nCoV may exploit the ACE2-mediated tissue-protective response to provide further cellular targets for entry.

In conclusion, the changes occurring in the expression level of ACE2 and its regulatory mechanism after the S protein of $\mathrm{CoV}$ binds to the ACE2 receptor remain unclear. If viral invasion downregulates ACE2 via adaptive protective mechanisms in the host this will inevitably cause RAS homeostasis impairment, thereby weakening the protective effect of ACE2 and leading to acute lung injury. If, on the other hand, ACE2 is upregulated, that will provide more receptors for viral entry and cause more viruses to invade host cells. Therefore, either upregulation or downregulation of ACE2 may have adverse consequences for the body. Perhaps during the period when cells are fighting the virus, ACE2 expression may be continuously changing (i.e., either up- or downregulated), and while human immune functioning is particularly important at this time, only those with robust immune functioning can defeat the virus (Fig. 4).

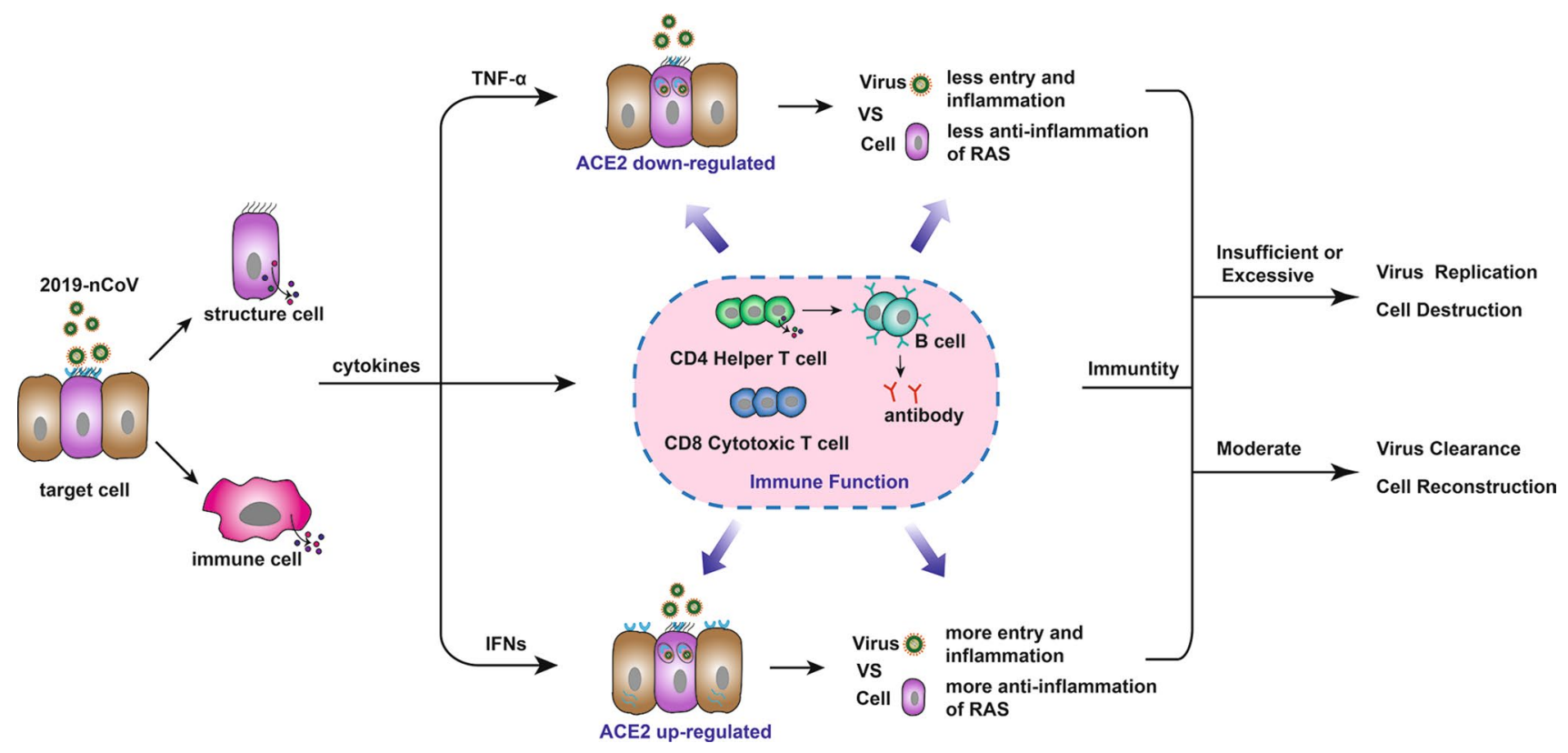

Fig. 4 Changes of ACE2 expression and key role of immune function after 2019-CoV infection. Invasion of 2019-nCoV to host cells induces nonspecific reactions of local tissue, releasing cytokines such as TNF- $\alpha$, IFNs, and so on. The expression of ACE2 may be downregulated by endocytosis and TNF- $\alpha$. At this point, although the viral invasion decreases, the local RAS is imbalance, reducing its anti-inflammatory effect. The expression of ACE2 may be upregulated by IFNs, enhancing the anti-inflammatory effect of local RAS, but also providing more entry for virus. Therefore, when cells and viruses fight, the human cellular and humoral immune function is particularly important. The insufficient or excessive immune responses will destroy their own tissue cells as a result of virus replication or cytokine storm. Only moderate immunity can clear viruses and restore cells 


\section{ACE2 expression in different organs and viral transmission pathways}

ACE2 is expressed in many different tissues at different levels, with an organ-specific distribution. It is highly expressed in the heart (coronary vascular endothelial cells, vascular smooth muscle, and cardiomyocytes, among other cells), kidneys (renal vessels and renal tubular epithelial cells) and testes. It is also found in the gastrointestinal tract and lungs [3, 59]. ACE2 expression levels and expression patterns in different tissues may be critical to the susceptibility, symptom manifestations, and outcome of infection with COVID-19. Therefore, it is hugely important to explore the expression characteristics of ACE2 in human tissues and its relationship with virus transmission, as well as determining the possible infection pathways for understanding the pathogenesis and treatment options for COVID-19.

The distributional expression of ACE2 in human tissues was reported as early as the SARS outbreak in 2003. It has been shown that the epithelial expression of ACE2 in lung and small intestine provided possible routes for SARS-CoV entry, and ACE2 is also expressed in vascular endothelium [60]. During their recent analysis of COVID19 , based on 43,134 cells derived from normal lung tissue of eight adult donors by single-cell RNA sequencing (RNA-Seq), the team at Tongji University Medical College (China) determined that more than $80 \%$ of ACE2 in the lungs was distributed on the surface of type II alveolar epithelial cells [61]. Other researchers found that ACE2 mRNA is mainly distributed in the small intestine, colon, duodenum, kidneys, testes and gallbladder by searching The Human Protein Atlas Database, but its expression level was low in the lungs, suggesting that some cells may upregulate ACE2 expression under certain conditions [33].

That ACE2 is expressed in different tissue types suggests that $\mathrm{CoV}$ infections may also involve the intestines, liver, kidneys, testes and other organs [62]. Previous studies have found that the proportion of patients infected SARS-CoV with diarrhea was as high as 70\% [63]. A recent case report showed the presence of 2019-nCoV in the feces from a patient who initially presented with diarrhea symptoms [64], and ACE2 has been found to be highly expressed in the upper esophagus, stratified epithelial cells, and absorptive enterocytes from the ileum and colon, findings consistent with the possibility of a fecal-oral transmission route [33, 65]. Liver dysfunction or injury in patients with NCP may be caused by the inappropriate use of antiviral drugs or systemic inflammatory reactions [66]. Recently, Zhao et al. [66] showed that 2019-nCoV could infect cholangiocytes expressing human-specific ACE2 using the human liver ductal organoids model, with resultant barrier and bile acid transport function impairment. Thus, liver damage in COVID-19 patients might partly result from direct cholangiocyte injury and consequent bile acid accumulation during 2019nCoV infection.

Acute kidney injury has also been seen in patients with 2019nCoV infections [67]. RNA-Seq has shown that ACE2 is abundantly expressed in various kidney proximal tubule cell subtypes. In addition to renal injury from host immune responses, renal injury may be caused by the virus directly attacking target cells where ACE2 is expressed [68]. Some researchers have indicated that 2019-nCoV may enter renal tubular cells by binding to ACE2, thereby inducing cytotoxicity and renal dysfunction [69]. One place where ACE2 is highly expressed is the testes, mainly in the spermatogonia, Sertoli cells and interstitial cells. Although there are no studies to establish whether 2019-nCoV infection causes testicular damage, some experts have highlighted the importance of evaluating reproductive function in recovered male patients, especially young ones [69].

It has been reported that $2019-\mathrm{nCoV}$ was present in blood from patients with COVID-19, suggesting that infection sometimes may be systemic [70]. Guo et al. [71] analyzed the single cell RNA-Seq data for normal whole lung tissue samples and fibrotic lung tissue samples and found that ACE2 was mainly expressed in the arterial vascular cells of fibrotic lungs. The first destination of pulmonary circulation outflow is the heart, and the failing human heart has a higher percentage of ACE2expressing cardiomyocytes. Therefore, it is assumed that 2019nCoV may attack the heart through the blood flow, which may explain the high incidence of cardiac injury in critically ill patients [71, 72]. The $31 \%$ incidence of thrombotic complications in ICU patients with COVID-19 infections is remarkably high [73]. In short, the flow of virus into the blood stream is a key step for its spread to other organs, body fluids and excreta, and provides the blood transmission pathways for 2019-nCoV.

In conclusion, in addition to the respiratory, digestive and genitourinary systems, the blood system may also be a potential route of infection for 2019-nCoV. More recent researches $[74,75]$ revealed that ACE2 and TMPRSS2 were co-expressed in ocular surface cells and nasal epithelium which could therefore serve as a portal of initial infection and transmission. Thus, it is important to clarify the mechanism of virus transmission for public health administration departments to formulate the best health policies regarding the prevention of 2019-nCoV infections.

\section{ACE2 in different species and populations and susceptibility to 2019-nCoV infection}

\section{ACE2 gene variation in different species and virus susceptibility}

The world is currently in a severe emergency state regarding 2019-nCoV, and the analysis of ACE2 in different 
species can help with providing a warning system for the cross-species transmission of 2019-nCoV.

Variation in the ACE2 gene sequence in different species is closely linked with viral susceptibility. During the SARS outbreak, Li et al. [76] used pseudovirus to infect 293T cells transfected by human, mouse or rat ACE2. Their results showed that mouse and rat ACE2-transfected cells were both less efficiently infected by pseudovirus than human ACE2-transfected cells, and the infection efficacy was significantly enhanced by incubation with human ACE2-transfected mouse 3T3 cells. In human ACE2, amino acid sites 30-41, 82-84 and 353-357 were shown to be involved in the interaction with the SARS-CoV S protein, with residues $31,35,38,82$ and 353 being the key positions [27]. Based on the latter residue positions, some researchers explored the effect of ACE2 variation in different species on their susceptibility to the virus. Holmes et al. [77] identified variation at the M82N position in rat ACE2 compared with that in the human ortholog, which contains a large $\mathrm{N}$-linked glycan at this position. The same study found that a $\mathrm{K} 353 \mathrm{H}$ mutation resulted in the lack of a hydrophobic pocket. In mouse ACE2, there are M82S and $\mathrm{K} 353 \mathrm{H}$ mutations. Therefore, ACE2 mutations in rat and mouse ultimately lead them to lack susceptibility to SARS-CoV. Moreover, research on rhesus monkeys experimentally infected with a pathogenic SARS-CoV strain showed that there are natural non-synonymous changes in the rhesus ACE2 gene, and further mutagenesis analysis showed that $\mathrm{Y} 217 \mathrm{~N}$, a natural mutation, caused ACE2 expression to be dramatically downregulated and reduced the viral entry [78]. Another study found an enhanced interaction between civets and SARS-CoV caused by an additional region covering residues 90-93 in ACE2 [79].

A recent study on hACE2 transgenic mice and wildtype mice infected with 2019-nCoV reported that viral antigens were found in the trachea, alveolar epithelial cells and macrophages of the hACE2 mice, but not in the wild-type mice, suggesting that mice are insusceptible to 2019-nCoV [36]. Zhou et al. [7] used HeLa cells expressing human, civet, pig, Chinese chrysanthemum bat or mouse ACE2 to conduct in vitro viral infection experiments, observing that all ACE2-expressing cells except those from mouse were infected by the virus. It is worth mentioning here that some researchers have compared the amino acid sequences of ACE2 from different species and found that human and non-human primates share identical sequences in some regional residues. The above critical residues $31,35,38,82$ and 353 of companion animals, domestic animals and wildlife animals are relatively conserved among them, while certain ones are variable. Changes in amino acid residues may lead to lower affinity viral binding, and certainly the presence of other variable regions cannot be excluded to compensate for such changes [80]. Thus, generic variation in the ACE2 gene can influence the susceptibility of different species to $\mathrm{CoV}$, which should alert us to the potential interspecies transmission of 2019-nCoV.

\section{ACE2 expression in different populations and viral susceptibility}

Exploring whether different populations are potentially susceptible to 2019-nCoV by analyzing ACE2 expression in different people could provide a valuable reference for effective and timely epidemic prevention. A recent RNASeq analysis of the ACE2 expression patterns in eight normal human lung transplant donors showed no association between the number of cells expressing ACE2 and donor age or smoking status. However, men had a higher proportion of ACE2-expressing cells than women [61], a finding highly consistent with an epidemiological investigation showing that most patients diagnosed with 2019-nCoV infection were male [81]. Asian males were also found to have a higher percentage of ACE2-expressing cells than white and African Americans in one study [61]. But in the current situation, the original epidemic has become a global outbreak, not only in Asia, but in Europe and America also. One study that analyzed large-scale transcriptomic datasets of normal lung tissue found no significant differences in ACE2 gene expression between race, age, or sex, whereas in smokers, ACE2 gene expression was upregulated [82, 83]. Elsewhere, ACE2 genes were found to be expressed in specific cell types related to smoking history and location. ACE2 was reported to be actively expressed in the goblet cells of smokers and club cells of non-smokers in the bronchial epithelium [83]. In the lungs, ACE2 expression is abundant in the remodeled type II alveolar epithelial cells of smokers. But the reasons for such differences in ACE2 expression related to tobacco smoking are obscure [83]. Some researchers have reported that ACE2 expression decreases with increasing age, and because ACE2 is on the X chromosome its level is higher in women than in men. The ACE2 level is low in men and the elderly, but this pattern does not match the characteristic of severely ill COVID-19 patients being mostly elderly males. Therefore, whether or not ACE2 expression is high or low is not a crucial factor affecting the prognosis of patients with COVID-19 [84].

Some researchers have investigated the genetic backgrounds of different populations through coding-region variants in ACE2 in terms of its diversity and variability, which may affect its function. Quantitative trait locus variations that may affect ACE2 expression were analyzed using the GTEx database (https://www.gtexportal.org/home/datasets), which enabled the genomic characteristics of ACE2 in different populations to be compared, and the results indicated that ACE2 expression may also show potential differences 
among different groups and races in Asia. However, there is no genomic evidence to support the existence of ACE2 mutants in different populations that can resist its binding to the CoV S protein [85]. Recently, Othman et al. [86] found that none of the eight ACE2 mutants they investigated had disrupted interactions with the 2019-nCoV RBD; hence, they proposed that the genetic polymorphism they investigated for ACE2 had a marginal effect on the affinity with 2019-nCoV RBD. Nevertheless, this research area would benefit from further in-depth investigations.

Recent studies on the epidemiological characteristics of COVID-19 have revealed that people with chronic diseases such as hypertension, diabetes, chronic obstructive lung disease and coronary heart disease are more likely to have serious infections $[1,87,88]$. Applying statistical methods to collect clinical cases, we previously found that the serum concentration levels of ACE2 were significantly elevated in patients with essential hypertension [89]. Recently, Chen et al. [90] showed that the level of myocardial ACE2 mRNA and protein in patients with heart failure had increased significantly above normal levels by RNA-Seq. Another study analyzed lung transcriptome samples from more than 700 COVID-19 patients with comorbidities, and found that ACE2 was highly expressed in these patients, as compared with the control group, and that ACE2 may be regulated by histone modifying enzymes, including KDM5B (lysine-specific demethylase). This finding suggests that patients with such comorbidities may have higher chances than normal of developing severe COVID-19 [91]. In conclusion, whether ACE2 is up- or downregulated, patients with underlying diseases may have more imbalanced RAS homeostasis, lower immunity and greater susceptibility to 2019-nCoV. Hence, more attention should be paid to this population to reduce their infection risk and disease severity.

\section{Summary and perspectives}

It has been suggested that 2019-nCoV, like SARS-CoV, invades host cells through ACE2 receptors, but there are also CD209L co-receptors for SARS-CoV [92]. Some scholars noted that ACE2 is widely expressed across a variety of organs and is expressed moderately but not highly in lung, which, however, is the major infected organ [93]. In addition to the factors that connect the respiratory system with the external environment, is there any receptor other than ACE2 that mediates the invasion of 2019-nCoV into the host? One study using molecular model fitting may have an answer to this in showing that Ang II receptor type 2 (AT2), a G-protein-coupled receptor, is abundantly expressed in lung tissues and may be another receptor for 2019-nCoV [93]. AT2 plays an antagonistic role with AT1 in the RAS system. Invasion of host cells by 2019-nCoV affects the expression of ACE2, and if ACE2 is re-incorporated into cells with AT2 as a possible co-receptor, it would accelerate the imblance of the RAS system, worsening the situation for patients. It remains unclear whether the AT2 co-receptor leads to a more serious imbalance between the classical ACE-AngII-AT1 receptor axis and the new ACE2-Ang-(1-7)-Mas homeostasis in the RAS system.

Clinical studies have shown that "cytokine storms", or the massive release of inflammatory factors, occur in critically ill patients, causing bodily tissue damage and multiple organ failure in critical patients [87]. CoV invades host cells through ACE2, which changes ACE2 expression and leads to increased levels of Ang II, a proinflammatory factor. Ang II contributes to "cytokine storms". Recently, studies have shown that 2019-nCoV directly affects the human spleen and lymph nodes by infecting tissue-resident $\mathrm{CD} 169^{+}$macrophages. 2019-nCoV also triggers macrophages to produce IL-6, a proinflammatory cytokine [94]. 2019-nCoV may directly infect lymphocytes, especially $\mathrm{T}$ cells, leading to lymphopenia and impaired antiviral responses. But the lymphocytes lack ACE2 expression, and whether alveolar macrophages can phagocytose the viral particles, transfering to lymphocytes remains unknown [95]. The internal mechanism by which the immune system and RAS system interact and regulate each other when 2019-nCoV infects host cells is unclear, and this lack of clarity needs to be solved urgently.

In effect, ACE2 plays a dual role in COVID-19 infections by first acting as a receptor for 2019-nCoV, and then as a protective molecule in the RAS system. It is currently unclear whether ACE2 acts as a human friend or foe during infection with 2019-nCoV. This review has attempted to summarize the up-to-date research on ACE2 in CoV disease, mainly focusing on $\mathrm{CoV}$ invasion, changes in the expression of ACE2 after viral binding, the effects of 2019-nCoV distribution on viral transmission, and genetic susceptibility to $2019-\mathrm{nCoV}$ in humans. It is hoped that the information in this review will provide a clearer picture of the pathogenic mechanism of 2019-nCoV, and act as a useful reference on ACE2 as a potential therapeutic target for COVID-19.

Acknowledgements We thank Sandra Cheesman, $\mathrm{PhD}$, from Liwen Bianji, Edanz Group China (www.liwenbianji.cn/ac), for editing the English text of a draft of this manuscript. This work was supported by grants from the National Natural Science Foundation of China (Grant nos. 81970359 and 81372029), and the Foundation of Key R\&D Program of Hebei Province (20277718D).

\section{Compliance with ethical standards}

Conflict of interest The authors report no conflicts of interest in this work. 


\section{References}

1. Zhou F, Yu T, Du R, Fan G, Liu Y, Liu Z, Xiang J, Wang Y, Song B, Gu X, Guan L, Wei Y, Li H, Wu X, Xu J, Tu S, Zhang Y, Chen H, Cao B (2020) Clinical course and risk factors for mortality of adult inpatients with COVID-19 in Wuhan, China: a retrospective cohort study. Lancet. https://doi.org/10.1016/s0140 -6736(20)30566-3

2. Li G, De Clercq E (2020) Therapeutic options for the 2019 novel coronavirus (2019-nCoV). Nat Rev Drug Discov 19(3):149-150. https://doi.org/10.1038/d41573-020-00016-0

3. Tipnis SR, Hooper NM, Hyde R, Karran E, Christie G, Turner AJ (2000) A human homolog of angiotensin-converting enzyme. Cloning and functional expression as a captopril-insensitive carboxypeptidase. J Biol Chem 275(43):33238-33243. https://doi. org/10.1074/jbc.M002615200

4. Donoghue M, Hsieh F, Baronas E, Godbout K, Gosselin M, Stagliano N, Donovan M, Woolf B, Robison K, Jeyaseelan R, Breitbart RE, Acton S (2000) A novel angiotensin-converting enzymerelated carboxypeptidase (ACE2) converts angiotensin I to angiotensin 1-9. Circ Res 87(5):E1-9. https://doi.org/10.1161/01. res.87.5.e1

5. Li W, Moore MJ, Vasilieva N, Sui J, Wong SK, Berne MA, Somasundaran M, Sullivan JL, Luzuriaga K, Greenough TC, Choe H, Farzan M (2003) Angiotensin-converting enzyme 2 is a functional receptor for the SARS coronavirus. Nature 426(6965):450454. https://doi.org/10.1038/nature02145

6. Kuba K, Imai Y, Rao S, Gao H, Guo F, Guan B, Huan Y, Yang P, Zhang Y, Deng W, Bao L, Zhang B, Liu G, Wang Z, Chappell M, Liu Y, Zheng D, Leibbrandt A, Wada T, Slutsky AS, Liu D, Qin C, Jiang C, Penninger JM (2005) A crucial role of angiotensin converting enzyme 2 (ACE2) in SARS coronavirus-induced lung injury. Nat Med 11(8):875-879. https://doi.org/10.1038/nm1267

7. Zhou P, Yang XL, Wang XG, Hu B, Zhang L, Zhang W, Si HR, Zhu Y, Li B, Huang CL, Chen HD, Chen J, Luo Y, Guo H, Jiang RD, Liu MQ, Chen Y, Shen XR, Wang X, Zheng XS, Zhao K, Chen QJ, Deng F, Liu LL, Yan B, Zhan FX, Wang YY, Xiao GF, Shi ZL (2020) A pneumonia outbreak associated with a new coronavirus of probable bat origin. Nature 579(7798):270-273. https://doi.org/10.1038/s41586-020-2012-7

8. Lu R, Zhao X, Li J, Niu P, Yang B, Wu H, Wang W, Song H, Huang B, Zhu N, Bi Y, Ma X, Zhan F, Wang L, Hu T, Zhou H, Hu Z, Zhou W, Zhao L, Chen J, Meng Y, Wang J, Lin Y, Yuan J, Xie Z, Ma J, Liu WJ, Wang D, Xu W, Holmes EC, Gao GF, Wu G, Chen W, Shi W, Tan W (2020) Genomic characterisation and epidemiology of 2019 novel coronavirus: implications for virus origins and receptor binding. Lancet 395(10224):565-574. https ://doi.org/10.1016/s0140-6736(20)30251-8

9. Wan Y, Shang J, Graham R, Baric RS, Li F (2020) Receptor recognition by novel coronavirus from Wuhan: an analysis based on decade-long structural studies of SARS. J Virol. https://doi. org/10.1128/JVI.00127-20

10. Xu X, Chen P, Wang J, Feng J, Zhou H, Li X, Zhong W, Hao $P$ (2020) Evolution of the novel coronavirus from the ongoing Wuhan outbreak and modeling of its spike protein for risk of human transmission. Sci China Life Sci 63(3):457-460. https:// doi.org/10.1007/s11427-020-1637-5

11. Cornell MJ, Williams TA, Lamango NS, Coates D, Corvol P, Soubrier F, Hoheisel J, Lehrach H, Isaac RE (1995) Cloning and expression of an evolutionary conserved single-domain angiotensin converting enzyme from drosophila melanogaster. J Biol Chem 270(23):13613-13619. https://doi.org/10.1074/jbc.270.23.13613

12. Taylor CAM, Coates D, Shirras AD (1996) The Acer gene of Drosophila codes for an angiotensin-converting enzyme homologue. Gene 181(1):191-197. https://doi.org/10.1016/S0378 $-1119(96) 00503-3$

13. Komatsu T, Suzuki Y, Imai J, Sugano S, Hida M, Tanigami A, Muroi S, Yamada Y, Hanaoka K (2002) Molecular cloning, mRNA expression and chromosomal localization of mouse angiotensin-converting enzyme-related carboxypeptidase (mACE2). DNA Seq 13(4):217-220. https://doi.org/10.1080/1042517021 000021608

14. Lambert DW, Yarski M, Warner FJ, Thornhill P, Parkin ET, Smith AI, Hooper NM, Turner AJ (2005) Tumor necrosis factor- $\alpha$ convertase (ADAM17) mediates regulated ectodomain shedding of the severe-acute respiratory syndrome-coronavirus (SARS-CoV) receptor, angiotensin-converting enzyme-2 (ACE2). J Biol Chem 280(34):30113-30119. https://doi.org/10.1074/jbc.M505111200

15. Guy JL, Lambert DW, Turner AJ, Porter KE (2008) Functional angiotensin-converting enzyme 2 is expressed in human cardiac myofibroblasts. Exp Physiol 93(5):579-588. https://doi. org/10.1113/expphysiol.2007.040139

16. Lew RA, Warner FJ, Hanchapola I, Yarski MA, Ramchand J, Burrell LM, Smith AI (2008) Angiotensin-converting enzyme 2 catalytic activity in human plasma is masked by an endogenous inhibitor. Exp Physiol 93(5):685-693. https://doi.org/10.1113/ expphysiol.2007.040352

17. Paul M, Poyan Mehr A, Kreutz R (2006) Physiology of local renin-angiotensin systems. Physiol Rev 86(3):747-803. https:// doi.org/10.1152/physrev.00036.2005

18. Santos RAS, Sampaio WO, Alzamora AC, Motta-Santos D, Alenina N, Bader M, Campagnole-Santos MJ (2018) The ACE2/ angiotensin-(1-7)/MAS axis of the renin-angiotensin system: focus on angiotensin-(1-7). Physiol Rev 98(1):505-553. https:// doi.org/10.1152/physrev.00023.2016

19. Hulswit RJ, de Haan CA, Bosch BJ (2016) Coronavirus spike protein and tropism changes. Adv Virus Res 96:29-57. https:// doi.org/10.1016/bs.aivir.2016.08.004

20. Zhu N, Zhang D, Wang W, Li X, Yang B, Song J, Zhao X, Huang B, Shi W, Lu R, Niu P, Zhan F, Ma X, Wang D, Xu W, Wu G, Gao GF, Tan W (2020) A novel coronavirus from patients with pneumonia in China, 2019. N Engl J Med 382(8):727-733. https ://doi.org/10.1056/NEJMoa2001017

21. Chen Y, Liu Q, Guo D (2020) Emerging coronaviruses: genome structure, replication, and pathogenesis. J Med Virol 92(4):418 423. https://doi.org/10.1002/jmv.25681

22. Li F (2012) Evidence for a common evolutionary origin of coronavirus spike protein receptor-binding subunits. J Virol 86(5):28562858. https://doi.org/10.1128/JVI.06882-11

23. Wu A, Peng Y, Huang B, Ding X, Wang X, Niu P, Meng J, Zhu Z, Zhang Z, Wang J, Sheng J, Quan L, Xia Z, Tan W, Cheng G, Jiang T (2020) Genome composition and divergence of the novel coronavirus (2019-nCoV) originating in China. Cell Host Microbe 27(3):325-328. https://doi.org/10.1016/j.chom.2020.02.001

24. Wu K, Li W, Peng G, Li F (2009) Crystal structure of NL63 respiratory coronavirus receptor-binding domain complexed with its human receptor. Proc Natl Acad Sci 106(47):19970-19974. https ://doi.org/10.1073/pnas.0908837106

25. Zhou Y, Hou Y, Shen J, Huang Y, Martin W, Cheng F (2020) Network-based drug repurposing for novel coronavirus 2019-nCoV/ SARS-CoV-2. Cell Discov 6(1):14. https://doi.org/10.1038/s4142 1-020-0153-3

26. Ramaiah A, Arumugaswami V (2020) Insights into crossspecies evolution of novel human coronavirus 2019-nCoV and defining immune determinants for vaccine development. bioRxiv:2020.2001.2029.925867. https://doi. org/10.1101/2020.01.29.925867

27. Li F, Li W, Farzan M, Harrison SC (2005) Structure of SARS coronavirus spike receptor-binding domain complexed with 
receptor. Science 309(5742):1864-1868. https://doi.org/10.1126/ science. 1116480

28. Tseng CT, Huang C, Newman P, Wang N, Narayanan K, Watts DM, Makino S, Packard MM, Zaki SR, Chan TS, Peters CJ (2007) Severe acute respiratory syndrome coronavirus infection of mice transgenic for the human angiotensin-converting enzyme 2 virus receptor. J Virol 81(3):1162-1173. https://doi.org/10.1128/ JVI.01702-06

29. McCray PB Jr, Pewe L, Wohlford-Lenane C, Hickey M, Manzel L, Shi L, Netland J, Jia HP, Halabi C, Sigmund CD, Meyerholz DK, Kirby P, Look DC, Perlman S (2007) Lethal infection of K18-hACE2 mice infected with severe acute respiratory syndrome coronavirus. J Virol 81(2):813-821. https://doi.org/10.1128/ JVI.02012-06

30. Yang X-h, Deng W, Tong Z, Liu Y-x, Zhang L-f, Zhu H, Gao H, Huang L, Liu Y-1, Ma C-m, Xu Y-f, Ding M-x, Deng H-k, Qin C (2007) Mice transgenic for human angiotensin-converting enzyme 2 provide a model for SARS coronavirus infection. Comp Med 57(5):450-459

31. Hoffmann M, Kleine-Weber H, Schroeder S, Kruger N, Herrler T, Erichsen S, Schiergens TS, Herrler G, Wu NH, Nitsche A, Muller MA, Drosten C, Pohlmann S (2020) SARS-CoV-2 cell entry depends on ACE2 and TMPRSS2 and is blocked by a clinically proven protease inhibitor. Cell. https://doi.org/10.1016/j. cell.2020.02.052

32. Yan R, Zhang Y, Guo Y, Xia L, Zhou Q (2020) Structural basis for the recognition of the 2019-nCoV by human ACE2. bioRxiv:2020.2002.2019.956946. https://doi. org/10.1101/2020.02.19.956946

33. Chen Y, Guo Y, Pan Y, Zhao ZJ (2020) Structure analysis of the receptor binding of 2019-nCoV. Biochem Biophys Res Commun. https://doi.org/10.1016/j.bbrc.2020.02.071

34. Wrapp D, Wang N, Corbett KS, Goldsmith JA, Hsieh C-L, Abiona O, Graham BS, McLellan JS (2020) Cryo-EM structure of the 2019-nCoV spike in the prefusion conformation. Science 367(6483):1260-1263. https://doi.org/10.1126/science.abb2507

35. Coutard B, Valle C, de Lamballerie X, Canard B, Seidah NG, Decroly E (2020) The spike glycoprotein of the new coronavirus 2019-nCoV contains a furin-like cleavage site absent in $\mathrm{CoV}$ of the same clade. Antiviral Res 176:104742. https://doi. org/10.1016/j.antiviral.2020.104742

36. Bao L, Deng W, Huang B, Gao H, Liu J, Ren L, Wei Q, Yu P, Xu Y, Qi F, Qu Y, Li F, Lv Q, Wang W, Xue J, Gong S, Liu M, Wang G, Wang S, Song Z, Zhao L, Liu P, Zhao L, Ye F, Wang H, Zhou W, Zhu N, Zhen W, Yu H, Zhang X, Guo L, Chen L, Wang C, Wang Y, Wang X, Xiao Y, Sun Q, Liu H, Zhu F, Ma C, Yan L, Yang M, Han J, Xu W, Tan W, Peng X, Jin Q, Wu G, Qin C (2020) The pathogenicity of SARS-CoV-2 in hACE2 transgenic mice. Nature. https://doi.org/10.1038/s41586-020-2312-y

37. Wang H, Yang P, Liu K, Guo F, Zhang Y, Zhang G, Jiang C (2008) SARS coronavirus entry into host cells through a novel clathrin- and caveolae-independent endocytic pathway. Cell Res 18(2):290-301. https://doi.org/10.1038/cr.2008.15

38. Haga S, Nagata N, Okamura T, Yamamoto N, Sata T, Yamamoto N, Sasazuki T, Ishizaka Y (2010) TACE antagonists blocking ACE2 shedding caused by the spike protein of SARS-CoV are candidate antiviral compounds. Antiviral Res 85(3):551-555. https://doi.org/10.1016/j.antiviral.2009.12.001

39. Haga S, Yamamoto N, Nakai-Murakami C, Osawa Y, Tokunaga K, Sata T, Yamamoto N, Sasazuki T, Ishizaka Y (2008) Modulation of TNF-alpha-converting enzyme by the spike protein of SARS$\mathrm{CoV}$ and ACE2 induces TNF-alpha production and facilitates viral entry. Proc Natl Acad Sci USA 105(22):7809-7814. https:// doi.org/10.1073/pnas.0711241105

40. Moore MJ, Dorfman T, Li W, Wong SK, Li Y, Kuhn JH, Coderre J, Vasilieva N, Han Z, Greenough TC, Farzan M, Choe H (2004)
Retroviruses pseudotyped with the severe acute respiratory syndrome coronavirus spike protein efficiently infect cells expressing angiotensin-converting enzyme 2. J Virol 78(19):10628-10635. https://doi.org/10.1128/JVI.78.19.10628-10635.2004

41. Towler P, Staker B, Prasad SG, Menon S, Tang J, Parsons T, Ryan D, Fisher M, Williams D, Dales NA, Patane MA, Pantoliano MW (2004) ACE2 X-ray structures reveal a large hinge-bending motion important for inhibitor binding and catalysis. J Biol Chem 279(17):17996-18007. https://doi.org/10.1074/jbc.M311191200

42. Heurich A, Hofmann-Winkler H, Gierer S, Liepold T, Jahn O, Pohlmann S (2014) TMPRSS2 and ADAM17 cleave ACE2 differentially and only proteolysis by TMPRSS2 augments entry driven by the severe acute respiratory syndrome coronavirus spike protein. J Virol 88(2):1293-1307. https://doi.org/10.1128/JVI.02202 $-13$

43. Ou X, Liu Y, Lei X, Li P, Mi D, Ren L, Guo L, Guo R, Chen T, Hu J, Xiang Z, Mu Z, Chen X, Chen J, Hu K, Jin Q, Wang J, Qian Z (2020) Characterization of spike glycoprotein of SARS-CoV-2 on virus entry and its immune cross-reactivity with SARS-CoV. Nat Commun 11(1):1620. https://doi.org/10.1038/s41467-020-15562 $-9$

44. Yan R, Zhang Y, Li Y, Xia L, Guo Y, Zhou Q (2020) Structural basis for the recognition of the SARS-CoV-2 by full-length human ACE2. Science. https://doi.org/10.1126/science.abb2762

45. Kowalczuk S, Bröer A, Tietze N, Vanslambrouck JM, Rasko JEJ, Bröer S (2008) A protein complex in the brush-border membrane explains a Hartnup disorder allele. FASEB J 22(8):2880-2887. https://doi.org/10.1096/fj.08-107300

46. Kuan TC, Yang TH, Wen CH, Chen MY, Lee IL, Lin CS (2011) Identifying the regulatory element for human angiotensin-converting enzyme 2 (ACE2) expression in human cardiofibroblasts. Peptides 32(9):1832-1839. https://doi.org/10.1016/j.pepti des.2011.08.009

47. Deshotels MR, Xia H, Sriramula S, Lazartigues E, Filipeanu CM (2014) Angiotensin II mediates angiotensin converting enzyme type 2 internalization and degradation through an angiotensin II type I receptor-dependent mechanism. Hypertension 64(6):13681375. https://doi.org/10.1161/HYPERTENSIONAHA.114.03743

48. Fernandes T, Hashimoto NY, Magalhaes FC, Fernandes FB, Casarini DE, Carmona AK, Krieger JE, Phillips MI, Oliveira EM (2011) Aerobic exercise training-induced left ventricular hypertrophy involves regulatory microRNAs, decreased angiotensinconverting enzyme-angiotensin ii, and synergistic regulation of angiotensin-converting enzyme 2 -angiotensin (1-7). Hypertension 58(2):182-189. https://doi.org/10.1161/HYPERTENSIONAHA .110 .168252

49. Imai Y, Kuba K, Rao S, Huan Y, Guo F, Guan B, Yang P, Sarao R, Wada T, Leong-Poi H, Crackower MA, Fukamizu A, Hui CC, Hein L, Uhlig S, Slutsky AS, Jiang C, Penninger JM (2005) Angiotensin-converting enzyme 2 protects from severe acute lung failure. Nature 436(7047):112-116. https://doi.org/10.1038/natur e03712

50. Oudit GY, Kassiri Z, Jiang C, Liu PP, Poutanen SM, Penninger JM, Butany J (2009) SARS-coronavirus modulation of myocardial ACE2 expression and inflammation in patients with SARS. Eur J Clin Invest 39(7):618-625. https://doi.org/10.111 1/j.1365-2362.2009.02153.X

51. Zhang H, Penninger JM, Li Y, Zhong N, Slutsky AS (2020) Angiotensin-converting enzyme 2 (ACE2) as a SARS-CoV-2 receptor: molecular mechanisms and potential therapeutic target. Intensive Care Med. https://doi.org/10.1007/s00134-02005985-9

52. Wang K, Gheblawi M, Oudit GY (2020) Angiotensin converting enzyme 2: a double-edged sword. Circulation. https://doi. org/10.1161/circulationaha.120.047049 
53. Wang S, Guo F, Liu K, Wang H, Rao S, Yang P, Jiang C (2008) Endocytosis of the receptor-binding domain of SARS-CoV spike protein together with virus receptor ACE2. Virus Res 136(1-2):815. https://doi.org/10.1016/j.virusres.2008.03.004

54. Liu Y, Yang Y, Zhang C, Huang F, Wang F, Yuan J, Wang Z, Li J, Li J, Feng C, Zhang Z, Wang L, Peng L, Chen L, Qin Y, Zhao D, Tan S, Yin L, Xu J, Zhou C, Jiang C, Liu L (2020) Clinical and biochemical indexes from 2019-nCoV infected patients linked to viral loads and lung injury. Sci China Life Sci 63(3):364-374. https://doi.org/10.1007/s11427-020-1643-8

55. Gheblawi M, Wang K, Viveiros A, Nguyen Q, Zhong JC, Turner AJ, Raizada MK, Grant MB, Oudit GY (2020) Angiotensinconverting enzyme 2: SARS-CoV-2 receptor and regulator of the renin-angiotensin system: celebrating the 20th anniversary of the discovery of ACE2. Circ Res 126(10):1456-1474. https://doi. org/10.1161/circresaha.120.317015

56. Monteil V, Kwon H, Prado P, Hagelkrüys A, Wimmer RA (2020) Inhibition of SARS-CoV-2 infections in engineered human tissues using clinical-grade soluble human ACE2. Cell. https://doi. org/10.1016/j.cell.2020.04.004

57. Zhuang MW, Cheng Y, Zhang J, Jiang XM, Wang L, Deng J, Wang PH (2020) Increasing host cellular receptor-angiotensinconverting enzyme 2 expression by coronavirus may facilitate 2019-nCoV (or SARS-CoV-2) infection. J Med Virol. https://doi. org/10.1002/jmv.26139

58. Ziegler CGK, Allon SJ, Nyquist SK, Mbano IM, Miao VN, Tzouanas CN, Cao Y, Yousif AS, Bals J, Hauser BM, Feldman J, Muus C, Wadsworth MH 2nd, Kazer SW, Hughes TK, Doran B, Gatter GJ, Vukovic M, Taliaferro F, Mead BE, Guo Z, Wang JP, Gras D, Plaisant M, Ansari M, Angelidis I, Adler H, Sucre JMS, Taylor CJ, Lin B, Waghray A, Mitsialis V, Dwyer DF, Buchheit KM, Boyce JA, Barrett NA, Laidlaw TM, Carroll SL, Colonna L, Tkachev V, Peterson CW, Yu A, Zheng HB, Gideon HP, Winchell CG, Lin PL, Bingle CD, Snapper SB, Kropski JA, Theis FJ, Schiller HB, Zaragosi LE, Barbry P, Leslie A, Kiem HP, Flynn JL, Fortune SM, Berger B, Finberg RW, Kean LS, Garber M, Schmidt AG, Lingwood D, Shalek AK, Ordovas-Montanes J (2020) SARS-CoV-2 receptor ACE2 is an interferon-stimulated gene in human airway epithelial cells and is detected in specific cell subsets across tissues. Cell 181(5):1016-1035.e1019. https:// doi.org/10.1016/j.cell.2020.04.035

59. Danilczyk U, Penninger JM (2006) Angiotensin-converting enzyme II in the heart and the kidney. Circ Res 98(4):463-471. https://doi.org/10.1161/01.RES.0000205761.22353.5f

60. Hamming I, Timens W, Bulthuis ML, Lely AT, Navis G, van Goor H (2004) Tissue distribution of ACE2 protein, the functional receptor for SARS coronavirus. A first step in understanding SARS pathogenesis. J Pathol 203(2):631-637. https://doi. org/10.1002/path.1570

61. Zhao Y, Zhao Z, Wang Y, Zhou Y, Ma Y, Zuo W (2020) Singlecell RNA expression profiling of ACE2, the receptor of SARSCoV-2. Am J Respir Crit Care Med. https://doi.org/10.1164/ rccm.202001-0179LE

62. Zou X, Chen K, Zou J, Han P, Hao J, Han Z (2020) Single-cell RNA-seq data analysis on the receptor ACE2 expression reveals the potential risk of different human organs vulnerable to 2019nCoV infection. Front Med. https://doi.org/10.1007/s 1168 4-020-0754-0

63. Hui DSC, Zumla A (2019) Severe acute respiratory syndrome: historical, epidemiologic, and clinical features. Infect Dis Clin N Am 33(4):869-889. https://doi.org/10.1016/j.idc.2019.07.001

64. Holshue ML, DeBolt C, Lindquist S, Lofy KH, Wiesman J, Bruce H, Spitters C, Ericson K, Wilkerson S, Tural A, Diaz G, Cohn A, Fox L, Patel A, Gerber SI, Kim L, Tong S, Lu X, Lindstrom S, Pallansch MA, Weldon WC, Biggs HM, Uyeki TM, Pillai SK, Washington State-nCo VCIT (2020) First case of 2019 novel coronavirus in the United States. N Engl J Med 382(10):929-936. https://doi.org/10.1056/NEJMoa2001191

65. Zhang H, Kang Z, Gong H, Xu D, Wang J, Li Z, Cui X, Xiao J, Meng T, Zhou W, Liu J, Xu H (2020) The digestive system is a potential route of 2019-nCov infection: a bioinformatics analysis based on single-cell transcriptomes. bioRxiv:2020.2001.2030.927806. https://doi. org/10.1101/2020.01.30.927806

66. Zhao B, Ni C, Gao R, Wang Y, Yang L, Wei J, Lv T, Liang J, Zhang Q, Xu W, Xie Y, Wang X, Yuan Z, Liang J, Zhang R, Lin $X$ (2020) Recapitulation of SARS-CoV-2 infection and cholangiocyte damage with human liver ductal organoids. Protein Cell. https://doi.org/10.1007/s13238-020-00718-6

67. Li Z, Wu M, Guo J, Yao J, Liao X, Song S, Han M, Li J, Duan G, Zhou Y, Wu X, Zhou Z, Wang T, Hu M, Chen X, Fu Y, Lei C, Dong H, Zhou Y, Jia H, Chen X, Yan J (2020) Caution on kidney dysfunctions of 2019-nCoV patients. medRxiv:2020.2002.2008.20021212. https://doi. org/10.1101/2020.02.08.20021212

68. Lin W, Hu L, Zhang Y, Ooi JD, Meng T, Jin P, Ding X, Peng L, Song L, Xiao Z, Ao X, Xiao X, Zhou Q, Xiao P, Fan J, Zhong Y (2020) Single-cell analysis of ACE2 expression in human kidneys and bladders reveals a potential route of 2019nCoV infection. bioRxiv:2020.2002.2008.939892. https://doi. org/10.1101/2020.02.08.939892

69. Fan C, Li K, Ding Y, Lu WL, Wang J (2020) ACE2 expression in kidney and testis may cause kidney and testis damage after 2019nCoV infection. medRxiv:2020.2002.2012.20022418. https://doi. org/10.1101/2020.02.12.20022418

70. Wang W, Xu Y, Gao R, Lu R, Han K, Wu G, Tan W (2020) Detection of SARS-CoV-2 in different types of clinical specimens. JAMA. https://doi.org/10.1001/jama.2020.3786

71. Guo J, Wei X, Li Q, Li L, Yang Z, Shi Y, Qin Y, Zhang X, Wang X, Zhi X, Meng D (2020) Single-cell RNA analysis on ACE2 expression provides insights into SARS-CoV-2 potential entry into the bloodstream and heart injury. J Cell Physiol. https://doi. org/10.1002/jcp.29802

72. Wang D, Hu B, Hu C, Zhu F, Liu X, Zhang J, Wang B, Xiang H, Cheng Z, Xiong Y, Zhao Y, Li Y, Wang X, Peng Z (2020) Clinical characteristics of 138 hospitalized patients with 2019 novel coronavirus-infected pneumonia in Wuhan, China. JAMA. https ://doi.org/10.1001/jama.2020.1585

73. Klok FA, Kruip M, van der Meer NJM, Arbous MS, Gommers D, Kant KM, Kaptein FHJ, van Paassen J, Stals MAM, Huisman MV, Endeman H (2020) Incidence of thrombotic complications in critically ill ICU patients with COVID-19. Thromb Res 191:145-147. https://doi.org/10.1016/j.thromres.2020.04.013

74. Zhou L, Xu Z, Castiglione GM, Soiberman US, Eberhart CG, Duh EJ (2020) ACE2 and TMPRSS2 are expressed on the human ocular surface, suggesting susceptibility to SARS-CoV-2 infection. Ocular Surf 18(4):537-544. https://doi.org/10.1016/j. jtos.2020.06.007

75. Sungnak W, Huang N, Bécavin C, Berg M, Queen R, Litvinukova M, Talavera-López C, Maatz H, Reichart D, Sampaziotis F, Worlock KB, Yoshida M, Barnes JL (2020) SARS-CoV-2 entry factors are highly expressed in nasal epithelial cells together with innate immune genes. Nat Med 26(5):681-687. https://doi.org/10.1038/ s41591-020-0868-6

76. Li W, Greenough TC, Moore MJ, Vasilieva N, Somasundaran M, Sullivan JL, Farzan M, Choe H (2004) Efficient replication of severe acute respiratory syndrome coronavirus in mouse cells is limited by murine angiotensin-converting enzyme 2 . J Virol 78(20):11429-11433. https://doi.org/10.1128/JVI.78.20.11429 $-11433.2004$ 
77. Holmes KV (2005) Adaptation of SARS coronavirus to humans. Science 309(5742):1822-1823. https://doi.org/10.1126/scien ce. 1118817

78. Chen Y, Liu L, Wei Q, Zhu H, Jiang H, Tu X, Qin C, Chen Z (2008) Rhesus angiotensin converting enzyme 2 supports entry of severe acute respiratory syndrome coronavirus in Chinese macaques. Virology 381(1):89-97. https://doi.org/10.1016/j.virol .2008.08.016

79. Li F (2008) Structural analysis of major species barriers between humans and palm civets for severe acute respiratory syndrome coronavirus infections. J Virol 82(14):6984-6991. https://doi. org/10.1128/JVI.00442-08

80. Li R, Qiao S, Zhang G (2020) Analysis of angiotensin-converting enzyme 2 (ACE2) from different species sheds some light on cross-species receptor usage of a novel coronavirus 2019-nCoV. J Infect. https://doi.org/10.1016/j.jinf.2020.02.013

81. Epidemiology Working Group for NCIP Epidemic Response, Chinese Center for Disease Control and Prevention (2020) The epidemiological characteristics of an outbreak of 2019 novel coronavirus diseases (COVID-19) in China. Zhonghua liu xing bing xue za zhi Zhonghua liuxingbingxue zazhi 41(2):145-151. https ://doi.org/10.3760/cma.j.issn.0254-6450.2020.02.003

82. Cai G, Bossé Y, Xiao F, Kheradmand F, Amos CI (2020) Tobacco smoking increases the lung gene expression of ACE2, the receptor of SARS-CoV-2. Am J Respir Crit Care Med 201(12):1557-1559. https://doi.org/10.1164/rccm.202003-0693LE

83. Cai G (2020) Bulk and single-cell transcriptomics identify tobacco-use disparity in lung gene expression of ACE2, the receptor of 2019-nCov. medRxiv:2020.2002.2005.20020107. https:// doi.org/10.1101/2020.02.05.20020107

84. Cheng H, Wang Y, Wang GQ (2020) Organ-protective effect of angiotensin-converting enzyme 2 and its effect on the prognosis of COVID-19. J Med Virol 92(7):726-730. https://doi.org/10.1002/ jmv. 25785

85. Cao Y, Li L, Feng Z, Wan S, Huang P, Sun X, Wen F, Huang X, Ning G, Wang W (2020) Comparative genetic analysis of the novel coronavirus (2019-nCoV/SARS-CoV-2) receptor ACE2 in different populations. Cell Discov 6:11. https://doi.org/10.1038/ s41421-020-0147-1

86. Othman H, Bouslama Z, Brandenburg JT, da Rocha J, Hamdi Y, Ghedira K, Srairi-Abid N, Hazelhurst S (2020) Interaction of the spike protein RBD from SARS-CoV-2 with ACE2: Similarity with SARS-CoV, hot-spot analysis and effect of the receptor polymorphism. Biochem Biophys Res Commun 527(3):702-708. https://doi.org/10.1016/j.bbrc.2020.05.028

87. Chen N, Zhou M, Dong X, Qu J, Gong F, Han Y, Qiu Y, Wang J, Liu Y, Wei Y, Xia Ja YuT, Zhang X, Zhang L (2020)
Epidemiological and clinical characteristics of 99 cases of 2019 novel coronavirus pneumonia in Wuhan, China: a descriptive study. Lancet 395(10223):507-513. https://doi.org/10.1016/s0140 $-6736(20) 30211-7$

88. Guan W-j, Ni Z-y, Hu Y, Liang W-h, Ou C-q, He J-x, Liu L, Shan H, Lei C-1, Hui DSC, Du B, Li L-j, Zeng G, Yuen K-Y, Chen R-c, Tang C-1, Wang T, Chen P-y, Xiang J, Li S-y, Wang J-1, Liang Z-j, Peng Y-x, Wei L, Liu Y, Hu Y-h, Peng P, Wang J-m, Liu J-y, Chen Z, Li G, Zheng Z-j, Qiu S-q, Luo J, Ye C-j, Zhu S-y, Zhong $\mathrm{N}$-s (2020) Clinical characteristics of coronavirus disease 2019 in China. N Engl J Med. https://doi.org/10.1056/NEJMoa2002032

89. Li S, Wang Z, Yang X, Hu B, Huang Y, Fan S (2017) Association between circulating angiotensin-converting enzyme 2 and cardiac remodeling in hypertensive patients. Peptides 90:63-68. https:// doi.org/10.1016/j.peptides.2017.02.007

90. Chen L, Li X, Chen M, Feng Y, Xiong C (2020) The ACE2 expression in human heart indicates new potential mechanism of heart injury among patients infected with SARS-CoV-2. Cardiovasc Res. https://doi.org/10.1093/cvr/cvaa078

91. Pinto BGG, Oliveira AER, Singh Y, Jimenez L, Gonçalves ANA, Ogava RLT, Creighton R, Peron JPS, Nakaya HI (2020) ACE2 expression is increased in the lungs of patients with comorbidities associated with severe COVID-19. J Infect Dis. https://doi. org/10.1093/infdis/jiaa332

92. Jeffers SA, Tusell SM, Gillim-Ross L, Hemmila EM, Achenbach JE, Babcock GJ, Thomas WD Jr, Thackray LB, Young MD, Mason RJ, Ambrosino DM, Wentworth DE, Demartini JC, Holmes KV (2004) CD209L (L-SIGN) is a receptor for severe acute respiratory syndrome coronavirus. Proc Natl Acad Sci USA 101(44):15748-15753. https://doi.org/10.1073/pnas.0403812101

93. Cui Q, Cui C, Huang C, Zhou W, Ji X, Zhang F, Wang L, Zhou Y (2020) AGTR2, one possible novel key gene for the entry of 2019-nCoV into human cells. Preprints: 2020020194. https://doi. org/10.20944/preprints202002.0194.v1

94. chen y, Feng Z, Diao B, Wang R, Wang G, Wang C, Tan Y, Liu L, Wang C, Liu Y, Liu Y, Yuan Z, Ren L, Wu Y (2020) The novel severe acute respiratory syndrome coronavirus 2 (SARS-CoV-2) directly decimates human spleens and lymph nodes. medRxiv:2020.2003.2027.20045427. https://doi. org/10.1101/2020.03.27.20045427

95. Li H, Liu L, Zhang D, Xu J, Dai H, Tang N, Su X, Cao B (2020) SARS-CoV-2 and viral sepsis: observations and hypotheses. Lancet. https://doi.org/10.1016/s0140-6736(20)30920-x

Publisher's Note Springer Nature remains neutral with regard to jurisdictional claims in published maps and institutional affiliations. 